\title{
The Han Dynasty-Xiongnu Relationship in the Early Western Han Dynasty: The Peace between the Enemies
}

\author{
Ming Sun
}

School of Mind, Brain, and Behavior (MBB) and School of International Languages, Literatures, and Cultures (SILLC), University of Arizona, Tucson, Arizona 85721, United States, mingsun@email.arizona.edu

\begin{abstract}
The Xiongnu chose to maintain a seeming friendship with the early Western Han Dynasty rather than start aggressive invasion even though the second century BC was the golden age of its expansion. The reasons of the peace period between the two hostile empires are deconstructed into three factors in this paper. Firstly, the Xiongnu's ideological confidence in pastoral nomadism prevented them from conquering China and converting themselves into sedentary citizens. Secondly, the military campaigns that the Xiongnu launched were possibly in accordance with their economic demand, namely, economic-motivated. Last but not least, the Han government implemented the strategy of peace-making marrige to supply the Xiongnu's nomadic economy with the Han goods, which effectively earned the peace agreement during this period.
\end{abstract}

Keywords: Xiongnu, Xiongnu Ideology, Xiongnu Economy, The Early Western Han Dynasty, Han Dynasty-Xiongnu Relationship, He-Qin.

\section{INTRODUCTION}

Xiongnu, the first united nomadic empire of the Inner Asian steppe, rapidly rose as one of the biggest challenges to its southern neighbor, the Western Han of China [1]. However, before Emperor $\mathrm{Wu}$ of Han changed his policy towards the Xiongnu from appeasement to active attacks in $134 \mathrm{BC}$, both the Xiongnu and the Han Dynasty agreed to maintain a superficial harmony during the most period of the $2^{\text {nd }}$ century BC. Thus, in its heydays, ruled by Maodun, Laoshang, and Junchen [2], the Xiongnu empire showed no attempt to defeat or conquer the Central Plains of China by launching massive warfare on a national level [3].

It was noticeable that the Xiongnu Empire forwent a further expansion into Han territory during the early Western Han period although the nomads was usually portrayed as the aggressive invaders from the perspective of the Han Dynasty. Since the modern scholars found no written records from the Xiongnu and only a limited number of archeological evidence was available for us, most of the studies on the Han Dynasty-Xiongnu relationship relied heavily on the Chinese accounts such as Shiji, Han Shu, and Hou Hanshu. Among those historical records, Sima Qian's Shiji, or Records of the Grand History of China, was a first-handed document that provided rich information about the Xiongnu Empire from its beginning to the time of Emperor Wu of Han. Using Shiji as a primary source, other textual and archeological materials as supplements, this paper tried to trace the possible rationales that a burgeoning Xiongnu Empire agreed to build a titular friendship with the Han Empire during the $2^{\text {nd }}$ century BC. The study examines this historical phenomenon from three major perspectives, including the Xiongnu's ideological confidence, their political economy as well as the Han's effective strategy. These three factors interconnected and shaped the surprising consensus between the two hostile superpowers.

\section{XIONGNU'S IDEOLOGICAL CONFIDENCE}

As far back as the pre-Qin period, the Chinese idea of the world order was based not only on geographical but also a moral and political Sino-centrism [4]. Adopted from the ancient imagination, a typical understanding of the world for the Han Chinese was exemplified by the five-zone theory [5]. The theory suggested that the observed world be divided into five zones in the form of concentric circles, in which the closer the area to the central zone the more control by the Son of Heaven [6] and the higher degree of civilization it has. The Xiongnu people were supposed to belong to the most outer circle named the wild zone in accordance with the theory, which meant that they were highly barbaric and unlikely to be civilized.

However, people of the Mongolian steppes have long developed indigenous nomadic pastoral cultures out of the northern frontier of China [7]. In consequence, the rise of the Xiongnu led to an ideological crisis of the 
Sinocentric worldview. The Xiongnu didn't incorporate themselves into the Han's model, on the contrary they had an independent understanding of their identity. As known to all, the Xiongnu people worshipped the Sun and Moon, Heaven and Earth, the ancestors and ghosts as well, which was similar to the Chinese. Nevertheless, given that the Xiongnu's supreme ruler "Shanyu" literally meant "Heaven's Son, the Magnificent," they claimed that it was the Xiongnu, not the Han, that was chosen by the Heaven. According to Sima Qian's documentation, a letter from Maodun to Emperor Wen started with "The great Shanyu whom Heaven has set up respectfully inquires of the emperor's health [8]." Maodun's successor Laoshang accepted the suggestion from his military advisor Zhonghang Yue, further expanded his title to "the great Shanyu of the Xiongnu, born of Heaven and Earth and ordained by the sun and moon" in the letter sent to the Han emperor [9]. The phrasing of their title not only manifested just the Shanyu's dignity, but also revealed a superiority complex to the Han emperor. Chinese scholar Cui Mingde used the term "self-esteem" to describe the Xiongnu's self-centered psychology and pointed out that the Xiongnu gained the highest self-esteem during the early Western Han [10]. A clear ideological dichotomy between the Han and the Xiongnu was therefore formed.

This ideological discrepancy was directly reflected in their mutually exclusive living way. As a Han defector whom the Shanyu later recognized, Zhonghang Yue once defended against the denunciation of Xiongnu culture from a Han envoy:

"...Therefore, in wartime the men practise riding and shooting, while in times of peace they enjoy themselves and have nothing to do...so that the governing of the whole nation is no more complicated than the governing of one person...Therefore, although the Xiongnu encounter times of turmoil, the ruling families always manage to stand firm [11]."

In Zhonghang Yue's opinion, compared with the agricultural-based Han, the Xiongnu established a better political system, which guaranteed a more leisurely life with higher quality. The passage conveyed an important message: the Xiongnu had sufficient reasons and confidence to practice their nomadic pastoralism. Under Sima Qian's narrative, Zhonghang Yue appeared as a plausible debater who humiliated the prejudiced Han envoy [12]. Though the narrator might have polished this persuasive speech, it indicated that the Xiongnu's pride in their indigenous culture had aroused the attention of Chinese elites in terms of challenging Han centrism. In another case, Zhonghang Yue alerted the Shanyu to the risk of having a fondness for Chinese culture. He believed that the strength of the Xiongnu came from their lives on the horseback and changes in the Xiongnu custom would ultimately corrupt and weaken them [13]. This idea reflected Xiongnu's understanding that it was nomadism that brought them power, while the agricultural Han culture represented only weakness. In other words, the Xiongnu did not value the living lifestyle of the Han, just as the Han disdained that of the Xiongnu inversely. Based on such a national consciousness that the Xiongnu revealed, living a sedentary life was unattractive compared to being nomadic pastoralists. Hence, in its golden age, the Xiongnu people were unlikely to invade the Han territory and established an agricultural-based political system for the reasons of converting themselves into sedentary citizens. This ideological confidence of the Xiongnu made them fundamentally different from several latter nomadic groups, who embraced the Chinese value and eventually assimilated into the Chinese sedentary history [14].

The Shiji did imply the possibility that the ideological dichotomy precluded the Shanyu from a desperate invasion toward Han. The military campaign that was closest to a full-scale war between Han and Xiongnu happened at around 200 B.C., which was later known as the "Battle of Baideng." Maodun's cavalry ambushed the vanguard of the Emperor Gaozu of Han on White Peak, near the border city Pingcheng. In Sima Qian's records, Gaozu bribed the Shanyu's consort. In order to prevent the intensification of the conflict, the consort said to Maodun:

"Why should the rulers of these two nations make such trouble for each other? Even if you gained possession of the Han lands, you could never occupy them, and the ruler of the Han may have his guardian deities as well as you. I beg you to consider the matter well! [15]"

The consort's choice of words like "the rulers of two nations" specified both the equal status and the incompatibility of the two parties. As was directly pointed out, the Xiongnu would not be able to rule the Han lands. Indeed, for the nomadic pastoralists who lacked interest in changing their existing way of living, it was neither feasible nor realistic to govern the dense population of the Han lands. Maodun's later withdrawal seemed to endorse the consort's idea. Though it would be over-simplified and dramatic to attribute such a statement to Maodun's decision, the passage certainly suggested that conquering the Han empire was not the primary goal for Maodun to launch this military campaign. The possible explanations of Maodun's retreat were diverse. For instance, the Xiongnu may concern about having no absolute military advantage to deal with the Han reinforcements as well as the possible defection of the Han surrenders. Historians also speculated that the Xiongnu aimed only to exhibit their strength to create a bargaining chip for a further negotiation to the Han, instead of defeating the Han. Therefore, a clear line was drawn between the two different cultural spheres, which both the Xiongnu and the Han were unwilling to across. On the one hand, the ideological confidence that the Xiongnu established led them to contend the center of authority with the Han. On the other hand, the mutual exclusiveness of two cultures brought incompetence to compromise to the opposite 
culture. Thus, under such a bipolar world order, the sense of identity and the consciousness of a pastoral lifestyle drove the Xiongnu to consider a further occupation of a vast agricultural land from the Han to be unnecessary and unappealing.

\section{THE EXPANSION AND THE POLITICAL ECONOMY}

The Xiongnu's ideological confidence could account for the absence of the more violent conflicts with the Han, however, it did not explain the Xiongnu's other military actions toward the agricultural world during its expansion. The expansionism of the Xiongnu Empire was undoubtedly a comprehensive historical phenomenon, but it is highly possible that the pursuit of political and economic benefits be an internal motive. By launching a series of military campaign, the Xiongnu revealed an implicit desire for deeper economic communication and cooperation with the sedentary culture.

Generally acknowledged as one of the distinguishing features shared among all nomadic pastoral groups, the commercial activities that enable them to exchange animal productions with the goods produced by the agricultural residents played a crucial role in the Xiongnu people's daily lives. Scholars had long debated whether the Xiongnu were economically dependent on their sedentary neighbors, explicitly referring to China and the oasis city-states in Central Asia [16]. Whereas, scholars from both sides had reached an indisputable consensus: these herders were enthusiastic about receiving grains, money, and artifacts from the farmers. Given that the unearthed Chinese silk, lacquerware, and bronze ware at the Noin-Ula burial site were abundant, the product from the Han was an important symbol of status for the Xiongnu nobles [17]. There were also rich textural evidence indicating Xiongnu's great passion for agricultural commodities. For example, the newly successive Emperor $\mathrm{Wu}$ opened trading ports at the frontier for the Xiongnu to maintain the peace treaty:

When the present emperor came to the throne he reaffirmed the peace alliance and treated the Xiongnu with generosity, allowing them to trade in the markets of the border stations and sending them lavish gifts. From the Shanyu on down, all the Xiongnu grew friendly with the Han, coming and going along the Great Wall [18].

Other descriptions of the flourishing border trade between the Han and the Xiongnu appeared in the later texts such as the Book of the Later Han and the Discourses on Salt and Iron [19]. Those records showed that not only the ruling class, but the Xiongnu laypeople also had a huge demand for goods exchange with the farmers. Therefore, even the Xiongnu were not necessarily fully dependent on the agricultural production, they did show a strong tendency to have them to show out the nobleness of the upper class or to trade and improve ordinary people's lives.
Shortly after the unification of various tribes under the Xiongnu confederacy, Maodun defeated two other competitive nomadic forces by driving the Yuezhi from the Gansu Corridor into the Western Regions and annexing the Eastern Barbarians in the East [20]. At roughly the same time, Maodun occupied the region called "south of the Yellow River" from China, which was experiencing the chaotic Qin-Han transition. This could be seen as the Xiongnu's first remarkable expansion toward the sedentary culture:

...[Maodun] annexed the lands of the ruler of Loufan and the ruler of Boyang south of the Yellow River. Thus he recovered possession of all the lands which the Qin general Meng Tian had taken away from the Xiongnu; the border between his territory and that of the Han empire now followed the old line of defences south of the Yellow River...[21]

The so-called "south of the Yellow River" refers to a transitional zone between the farmland and the grassland, where the people have long practiced a semi-pastoralism, a mixed economy between farming and herding. During the short-lived Qin Dynasty (221-206 BC), as Sima Qian wrote, this region was included into the Chinese territory under Meng Tian's attack. it had significant economic value for the growing Xiongnu Empire to resume this area. For instance, the cereals that the Chinese residents grew can greatly supplement the livestock-based diet. Even though the archeological sites at Transbaikalia and Ivolga proved that the Xiongnu people had engaged in independent agriculture to a certain extent [22], as Sergei Rudenko states, agricultural production in the Xiongnu territory was still dominated by the Han residents [23]. In addition, once the farming land was under the control of the Xiongnu, they could directly acquire the agricultural production from their sedentary citizens by either trading or establishing the tributary system. While the existing evidence are unable to restore the specific political-economic policy that the Xiongnu implemented in the south of the Yellow River, the Xiongnu's later expansion into Central Asia manifested that a systematic acquiring from their controlled agricultural citizens was highly possible existed.

The domination of Central Asia was a powerful example that the Xiongnu's military expansion was linked to their pursuit of the political-economic benefits. The goods exchanged between different groups could be done through trading, raiding, giving and tributing etc. Before the Xiongnu conquering the Central Asia, the trading networks was fragile and impacted by the frequently changed political situations among separate forces. Furthermore, the raiding was also a defective choice, which was often accompanied by a waste of military strength and provided only a short-term effect. Due to the massive demand for substantial supplies from the agricultural states, the Xiongnu was forced to create a stable political environment to freely practice the nomadic pastoral economy without restriction. Taking 
over Central Asia was surely a gradual process, but it had mostly completed during Laoshang Shanyu's reign. At the time, from the oasis city-states in the Tarim Basin like Loulan and Gushi, to the Iranian-Sogdian of the Tian Shan-Pamir Mountains like Dayuan and Kangju, various regimes in this vast area were all under Xiongnu hegemony. When the Han diplomatist Zhang Qian firstly visited the Western Regions at around $138 \mathrm{BC}$, almost the whole Central Asia had officially recognized the Xiongnu as their suzerain. [24] The Xiongnu's rule over the Central Asia guaranteed at least two major economic sources: the right of free trade with those states and the tributary payments from them. The commodities moving among Central Asia were not only their local products but also exotic staffs from further west. The textiles found in Noin-Ula included the Greco-Bactrian hangings made by Yuezhi or Wusun and the tapestries from Parthia and Asia Minor [25]. The support from this region was so crucial to the Xiongnu that Zhang Qian described it as the right arm of the Xiongnu [26]. Modern scholar Di Cosmo also mentioned that the Western Regions was one of Xiongnu's power base [27]. If we accepted Sima Qian's description that Emperor Wu's long-distance military expedition to Dayuan was just for having their fine horses [28], then the Xiongnu, who were much closer to Central Asia, undoubtedly found the value of ruling them much earlier.

It is important to note that the idea that the territorial expansion of the Xiongnu Empire was economic motivated remains only in the stage of the assumption. Chinese textual sources like the Shiji selected only the "major events" and "valuable information" to record. Consequently, the Xiongnu's official interaction with the Han took the spotlight of the narration, while many Xiongnu political and economic details were overlooked. Accordingly, the existing archeological evidence, unfortunately, was also unable to reconstruct the exact causation between their economic demands and military use. However, it was not unreasonable that the Xiongnu needed to offer themselves a more favorable term for practicing their pastoralist economy. Once we hypothesize that their diplomatic and military actions were, at least partially, based on their pursuit of the stable income from their agricultural neighbors, the effectiveness of Han's strategy would become much more understandable.

\section{HAN'S STRATEGY}

Just like the occupation of south of the Yellow River and the domination of Central Asia, it was also part of the Xiongnu's military strategies to conquer the Han's cities in its northern frontier to sustain their economy. Such regional conflicts between the Xiongnu and the Han reached the peak at the beginning of the second century $\mathrm{BC}$. After the "Battle of Baideng," the newly established Han court realized that launching military strike was not a viable strategy for the threat of Xiongnu. The Han governors began to adopt the famous $\mathrm{He}$-Qin policy.
He-Qin, namely the "alliance through kinship," is probably the only means for the early Western Han to keep peace with the Xiongnu. Through marrying Chinese princesses to the Xiongnu Shanyu, the He-Qin system entailed diplomatic equality and a "brotherhood" between the two empires [29]. Making the Great Wall as the border, the two rulers respectively ran half of the World under Heaven, and the Xiongnu's devastation and raiding at the frontier settlements were therefore restricted [30]. However, the intermarriage itself may not be convincing enough for the Xiongnu to accept such an agreement since the Xiongnu were playing the leading role in the game and were likely to know that sometimes the so-called Han "princesses" were designated commoners. The critical point of the He-Qin system was the bountiful goods as the betrothal gifts given along with such political marriage.

Those namely gifts essentially established a tributary system, an official trading system in which Xiongnu paid nothing back. The traditional Chinese view on $\mathrm{He}$-Qin was of an "unequal treaty of the economy [31]." Firstly, the Han annually provided gifts to the Xiongnu, regardless of whether an imperial marriage occurred or not. According to Sima Qian, those gifts were mainly "silk floss and cloth, grain, and other food stuffs. [32]" The Han political thinker Jia Yi, in one of his memoirs, also mentioned that the yearly gifts refer to money, silk floss, and fabrics [33]. Besides, the Shiji mentioned several times that the Han emperors sent luxuries to the Shanyu under the name of personal greetings [34]. Furthermore, starting from Emperor Wen and Shanyu Laoshang, opening trading markets at the border was added to the H-Qin agreement [35]. As mentioned earlier, unlike the presents that were only for the Xiongnu upper classes, the border trade brought tremendous profits to the common nomads like the merchants. To summarize, the tributary system under the name of gift giving consisted of the dowry accompanied by the imperial marriage, the yearly tribute, the additional gifts for specific reasons, and opening the official trading ports. Thus, the so-called He-Qin agreement was essentially an economic treaty, which was in great accordance with the Xiongnu demand on their political economy that was discussed in the previous section. The economic benefits the Xiongnu took from the $\mathrm{He}$-Qin, a conservative estimate, could have been as huge as they received from those states that they actually controlled in Central Asia.

According to Liu Jing, a key proposer of He-Qin, the Han initial purpose was to restrain the Xiongnu invasion through establishing the nominal kinship, which the economic terms were attached [36]. Jia Yi later offered a theory called "Three Principles and Five Baits", which saw the He-Qin as a tool of cultural infiltration. As Zhonghang Yue alerted, Jia Yi pointed out that the Han lavish gifts would increase the Xiongnu dependency on the Han's material, corrupt the Xiongnu's sense, desire, and their national identity [37]. It was hard to answer that whether the Xiongnu, due to the He-Qin strategy, 
had become increasingly dependent on the Han or not as the most recent studies on the Xiongnu tend to draw a more complex social-political structure than people traditionally thought. Therefore, some scholars started to argue that the Xiongnu people were self-sufficient, which means they were able to sustain without the Han's supplies. The Han court led by the Emperor Wu, similarly, negated that the He-Qin had successfully corrupted the Xiongnu for rationalizing their long-prepared military attack.

Despite the He-Qin's possible fail to fulfill the Han task of weakening the Xiongnu culture, it did contribute to the harmonious relationship between the two empires during the early Western Han. As the Han expected, their appeasement policy became quickly effective in terms of minimizing the border conflicts:

...The Han agreed to send a gift of specified quantities of silk floss and cloth, grain, and other food stuffs each year, and the two nations were to live in peace and brotherhood. After this Maodun raided the frontier less often than before [38].

Since then every time a new emperor took the throne and renewed the friendly relationship by implementing the He-Qin activities, it ushered in a harmonious coexistence for years. A typical example was that the newly successive Emperor Wu renewed the He-Qin agreement. At the time, "From the Shanyu on down, all the Xiongnu grew frendly with the Han. [39]" Modern scholars like Yu Yingshi, Rev. H. Serrucys, and Hilda Ecsedy had separately studied on the interactions between ancient China and its nomadic invaders at different time periods [40]. According to their views on the impact of the trading crisis on the nomadic military policy, the blocking of economic trade significantly contributed to nomadic invasions of ancient China. Conversely, taking this point to the Xiongnu's absence on massive invasion in our case, the He-Qin policy that went with the Xiongnu's economic demand was an effective means that prevented the potentially greater military actions of the Xiongnu empire.

Admittedly, the peace treaty did not contribute to absolute harmony, as the border conflicts still happened occasionally. For example, in the third year of the reign of Emperor Wen, the Xiongnu Wise King of the Right plundered and killed many barbarians that were already under the shelter of the Han. Emperor Wen wrote a letter to Shanyu and censured the Xiongnu's treachery on their "brotherhood." The Shanyu replied in a long letter with a diplomatic tone, explained the alleged misunderstanding, pointed out that it was a personal action of the Wise King of the Right, who had received a punishment for that. At the end of this reply, the Shanyu said:

"Thus I wish now to lay down my weapons, rest my soldiers, and turn my horses to pasture; to forget the recent affair and restore our old pact, that the peoples of the border may have peace such as they enjoyed in former times, that the young may grow to manhood, the old live out their lives in security, and generation after generation enjoy peace and comfort. [41]"

The paragraph clearly showed that, though the Xiongnu seemed to have no ability of carrying out the covenant perfectly, they still wanted to hold the agreement on an official level. In other words, the temptation of the advantages brought by $\mathrm{He}$-Qin was enormous. Overall, as an appeasement policy, the heqin system effectively protected the vulnerable peace between the Han and the Xiongnu by accurately meeting the Xiongnu's economic demand.

\section{CONCLUSION}

Based on the ideological confidence of being the nomadic pastoralist, the Xiongnu people were less motivated to large-scale aggression towards the Han for a cultural transformation from nomadism to farming. Instead, a key motive of their expansion could be the severe demand of economic interactions with sedentary cultures. According to such demand, Xiongnu had less interest in simply aggression than making agreements with the Han when the economic advantage they took from He-Qin was huge enough. It was Xiongnu's long-term interest to maintaining such a stable situation through the $\mathrm{He}$-Qin system.

We may infer that the dichotomy between the nomadic Xiongnu and sedentary China in the early Western Han period is not replicable through the study. Both the Xiongnu's ideology, its political economy, and the effectiveness of Han's foreign policy shaped the singularity of this time. Therefore, it is inappropriate to assume the nomads like Xiongnu would inherently move down to the sedentary civilization and cause social instability through all historical periods. In other words, the Han Dynasty-Xiongnu relationship cannot be simply approached by the model portrayed from a Sinocentric perspective, in which the northern nomads were intrinsically and constantly voracious. Even though throughout history, there were a number of nomadic groups which attempted to conquer a significant part of China, and such non-Han regimes did repeatedly establish during the Chinese history, it shall be aware of the complexity and uniqueness of the peaceful relationship between the Xiongnu and the Han in the second century BC.

\section{REFERENCES}

[1]. In around 208-202 BC, Maodun greatly expanded the Xiongnu territory to all directions. () The Western Han Dynasty, 202 BC-9 AD.

[2]. The first three Shanyu of the Xiongnu Empire ruled around $210 \mathrm{BC}$ to $126 \mathrm{BC}$.

[3]. The Central Plains 中原 refers to the political center of the China. Xiongnu did have military conflicts with the Han during this time, but none of them seems to aim to defeat the Han Dynasty. 
[4]. The pre-Qin period is the early China before Qin Shi Huang's unification in 221 BC, which specifically refers to the Xia, Shang, and Zhou Dynasties.

[5]. For Han's understanding to the world and the five-zone theory, see Denis Twitchett and Michael Loewe, "The World Order of Han China: Theory and Practice," in The Cambridge History of China Volume I The Ch'in and Han Empires 221 B.C.-A.D. 220 (Cambridge University Press, 1986), 337-383.

[6]. The Son of Heaven, the title of the Chinese emperor.

[7]. For the early development of pastoral societies in the northern frontier of China, see Nicola Di Cosmo, Ancient China and its Enemies: The Rise of Nomadic Power in East Asian History (Cambridge), 44-90.

[8]. Sima Qian. Shiji 110. Watson Burton. Records of the grand historian of China, Vol. 2 (Columbia University Press. 1971), 50.

[9]. Sima Qian. Shiji 110. Watson Burton. Records of the grand historian of China, Vol. 2 (Columbia University Press. 1971), 52.

[10]. Cui Mingde, "On the Self-esteem of Hun Leader in the Han Dynasty," China's Borderland History and Geography Studies, 2008, 18, no. 1.

[11]. Sima Qian. Shiji 110. Watson Burton. Records of the grand historian of China, Vol. 2 (Columbia University Press. 1971), 52-53.

[12]. Xinyuan Yu. Sima Qian's Imperial Dilemma. (Oxford and Empie Network) https://oxfordandempire.web.ox.ac.uk/article/simaqians-imperial-dilemma\#_ftn1

[13]. "The strength of the Xiongnu lies in the very fact that their food and clothing are different from those of the Chinese, and they are therefore not dependent upon the Han for anything. Now the Shanyu has this fondness for Chinese things and is trying to change the Xiongnu customs. Thus, although the Han sends no more than a fifth of its goods here, it will in the end succeed in winning over the whole Xiongnu nation." Sima Qian. Shiji 110. Watson Burton. Records of the grand historian of China, Vol. 2 (Columbia University Press. 1971), 52.

[14]. Acknowledged as part of the Chinese history, nomadic-originated groups established many Chinese sedentary dynasties in the later history, such as the Northern Dynasties in Medieval China, Liao and Jin Dynasties during the Song China, the Mongolian-ruled Yuan Dynasty, and the Qing Dynasty.

[15]. Sima Qian. Shiji 110. Watson Burton. Records of the grand historian of China, Vol. 2 (Columbia University Press. 1971), 49.

[16]. The discussion on how independency or dependency influences the Xiongnu formation and its politics, see Nicola Di Cosmo. Ancient China and its Enemies: The Rise of Nomadic Power in
East Asian History (Cambridge). 169-174.

[17]. Руденко. С. И., Sun Wei, trans. Kul'tura Khunnov I Noinulinskie Kurgany - Huns culture and the large tomb of Nuoyanwula. (Zhonghua shu ju, 2012), 134.

[18]. Sima Qian. Shiji 110. Watson Burton. Records of the grand historian of China, Vol. 2 (Columbia University Press. 1971), 55.

[19]. Esson M. Gale, Discourses on Salt and Iron (Leiden: Brill, 1931; rpt. Taipei: Ch'eng-wen, 1967). 14

[20]. The Western Regions, the Chinese term for Central Asia. "...they inflicted a crushing defeat, killing the ruler of the Eastern Barbarians, taking prisoner his subjects, and seizing their domestic animals. Then he returned and rode west, attacking and routing the Yuezhi..." Sima Qian. Shiji 110. Watson Burton. Records of the grand historian of China, Vol. 2, (Columbia University Press. 1971), 47.

[21]. Sima Qian. Shiji 110. Watson Burton. Records of the grand historian of China, Vol. 2 (Columbia University Press. 1971), 47.

[22]. N.N. Kradin. Iron age societies of Western Transbaikalia: Reconstruction of diet and lifeways. (Journal of Archaeological Science: Reports. Volume 38, August 2021, 102973)

[23]. Руденко. С. И., Sun Wei, trans. Kul'tura Khunnov I Noinulinskie Kurgany - Huns culture and the large tomb of Nuoyanwula. (Zhonghua shu ju, 2012), 134.

[24]. The history of the Han contending for rule of Central Asia with the Xiongnu refers to The Account of Dayuan: Sima Qian. Shiji 123. Watson Burton. Records of the grand historian of China, Vol. 2 (Columbia University Press. 1971), 231-252.

[25]. Руденко. С. И., Sun Wei, trans. Kul'tura Khunnov I Noinulinskie Kurgany - Huns culture and the large tomb of Nuoyanwula. (Zhonghua shu ju, 2012), 114-115.

[26]. "If we could get them to obey us, it would be like cutting off the right arm of the Xiongnu!" Sima Qian. Shiji 123. Watson Burton. Records of the grand historian of China, Vol. 2 (Columbia University Press. 1971), 238.

[27]. Nicola Di Cosmo, Ancient China and its Enemies. The Rise of Nomadic Power in East Asian History (Cambridge), 249-251.

[28]. "The reasons the Han has sent troops to attack us is simply that our king Wugua hid his best horses and killed the Han envoys." Sima Qian. Shiji 123. Watson Burton. Records of the grand historian of China, Vol. 2 (Columbia University Press. 1971), 249.

[29]. Mark Edward Lewis. The Early Hinese Empires, Qin and Han. (The Belknap Press of Harvard University Press. 2007.) 133.

[30]. "According to the decree of the former emperor, the land north of the Great Wall, where men wield the bow and arrow, was to receive its commands 
from the Shanyu, while that within the wall, whose inhabitants dwell in houses and wear hats and girdles, was to be ruled by us; thus might the countless inhabitants of these lands gain their food and clothing by agriculture, weaving, or hunting; father and son live side by side; ruler and minister enjoy mutual security; and all forsake violence and rebellion." Sima Qian. Shiji 110. Watson Burton. Records of the grand historian of China, Vol. 2 (Columbia University Press. 1971), 54.

[31]. For the Han opinions on the heqin policy, see Ying-shih Yu. Trade and expansion in Han China: a study in the structure of Sino-barbarian economic relations. (University of California Press. 1967.) 9-16

[32]. "The Han agreed to send a gift of specified quantities of silk floss and cloth, grain, and other food stuffs each year, and the two nations were to live in peace and brotherhood." Sima Qian. Shiji 110. Watson Burton. Records of the grand historian of China, Vol. 2 (Columbia University Press. 1971), 50.

[33]. Ban Gu. Han Shu 18.

[34]. For example, 174 BC, Emperor Wen sent the Shanyu "an embroidered robe lined with patterned damask, an embroidered and lined underrobe, and a brocaded coat, one each; one comb; one sash with gold ornaments; one gold-ornamented leather belt; ten rolls of embroidery; thirty rolls of brocade; and forty rolls each of heavy red silk and light green silk." Sima Qian. Shiji 110. Watson Burton. Records of the grand historian of China, Vol. 2 (Columbia University Press. 1971), 51.

[35]. Denis Twitchett and Michael Loewe. The Cambridge History of China Volume I The Ch'in and Han Empires 221 B.C.-A.D. 220 (Cambridge University Press, 1986), 388.

[36]. Cui Mingde. Lianghan Minzu Guanxi Sixiangshi. Beijing: Renmin chubanshe, 2007. 28-32. Tamara Chin. Defamiliarizing the Foreigner: Sima Qian's Ethonography and Han-Xiongnu Marriage Diplomacy. (Harvard Journal of Asiatic Studies. December 2010. Vol. 70. No. 2.) 349.

[37]. Cui Mingde. Lianghan Minzu Guanxi Sixiangshi. Beijing: Renmin chubanshe, 2007. 54-63. Tamara Chin. Defamiliarizing the Foreigner: Sima Qian's Ethonography and Han-Xiongnu Marriage Diplomacy. (Harvard Journal of Asiatic Studies. December 2010. Vol. 70. No. 2.) 349.

[38]. Sima Qian. Shiji 110. Watson Burton. Records of the grand historian of China, Vol. 2 (Columbia University Press. 1971), 50.

[39]. Sima Qian. Shiji 110. Watson Burton. Records of the grand historian of China, Vol. 2 (Columbia University Press. 1971), 55.

[40]. For the summarization of various studies on the reasons of the nomadic invasions of China, see Xiao Qiqing. "The Causes of Nomadic Invasions: A Synthesis" Shihuo Yuekan. 1.12 (1972): 1-11.
[41]. Sima Qian. Shiji 110. Watson Burton. Records of the grand historian of China, Vol. 2 (Columbia University Press. 1971), 50-51. 